\title{
The Economics of Native Subsistence Activities in a Village of Southwestern Alaska
}

\author{
MICHAEL NOWAK 1
}

\begin{abstract}
It is demonstrated that while it is difficult to arrive directly at values for the products of traditional subsistence activities, such values are necessary for the making of an assessment of actual and potential savings realizable through the use of traditional foods. These savings can account for one-quarter of the total real income of a family, although it is possible that inflation will decrease this amount in the future. The cost of basic equipment required for traditional subsistence activities and the total amount of flesh obtained are the primary determinants of final expense to the hunter.
\end{abstract}

RÉSUMÉ L'économie des activités traditionnelles de chasse et de pêche déployées par les indigènes dans un village du sud-ouest de l'Alaska. L'auteur démontre qu'alors qu'il est difficile d'arriver à une évaluation directe des produits résultant d'activités traditionnelles de chasse et de pêche déployées par les indigènes, cette évaluation est néanmoins nécessaire pour arriver à connaître le montant des économies réalisables en fait et potentiellement grâce à l'utilisation de cette nourriture traditionnelle. Ces économies peuvent représenter un quart du revenu réel total d'une famille, bien que l'inflation puisse en diminuer le montant à l'avenir, le coût de l'équipement de base nécessaire à ces activités traditionnelles et la quantité totale de viande obtenue représentent pour le chasseur les facteurs déterminants primordiaux de la dépense finale.

PE3IOМЕ. Экономика традичионного промысла в поселениях коренного населения гого-западной Аляски. Показано, что, несмотря на трудности определения непосредственной стоимости продуктов традиционного промысла, такие оденки необходимы для вычисления реальных и потенциальных сбережкении ва счет потребления традиционной пищи. Эти сбережения могут составлять до одноц четверти общего реального дохода семьи, хотя возможно, что инфляция будет их уменьшать. Стоимость основного оборудования, необходимого для традиционного промысла, и общее количество добытого мяса являвотея определяющими әлементамн при расчете конечных расходов охотника.

\section{INTRODUCTION}

In the continuing process of the acculturation of northern peoples, a matter of considerable interest is the degree to which traditional hunting and fishing activities are being affected. The subject has been investigated from several angles in recent years: for example, Kemp (1971) undertakes a thorough, novel analysis of energy flow (calorific input and output), using as his subjects members of a modern Eskimo community on Baffin Island; while Usher (1976) deals with traditional subsistence activities in terms of the direct food value of secured game, and also briefly considers some of the secondary products of the activities, such as hides, oils, and other non-food items. In the present study, three factors are taken account of in an attempt to assess the economic value of hunting and fishing in an Eskimo community on the southwestern coast of Alaska: the increasing participation of

1Colorado College, Colorado Springs, Colorado, U.S.A. and U.S. Fish and Wildlife Service, 813 D Street, Anchorage, Alaska 99501, U.S.A. 
native people in wage employment which restricts their opportunities for engaging in traditional hunting and fishing activities, the cost of equipment required in the pursuit of these activities, and the prices of store-obtained foods. Dietary factors are considered also.

The principal data used in the study were collected by the author during a period of four months he spent among the Nunivagamiut in 1973, when members of nine families provided detailed information concerning traditional subsistence foods, and members of four others were closely consulted in the making of the estimates used. Additional data were obtained while the author was on Nunivak Island (Fig. 1) in the summers of 1967, 1969, 1970, 1975 and 1976.

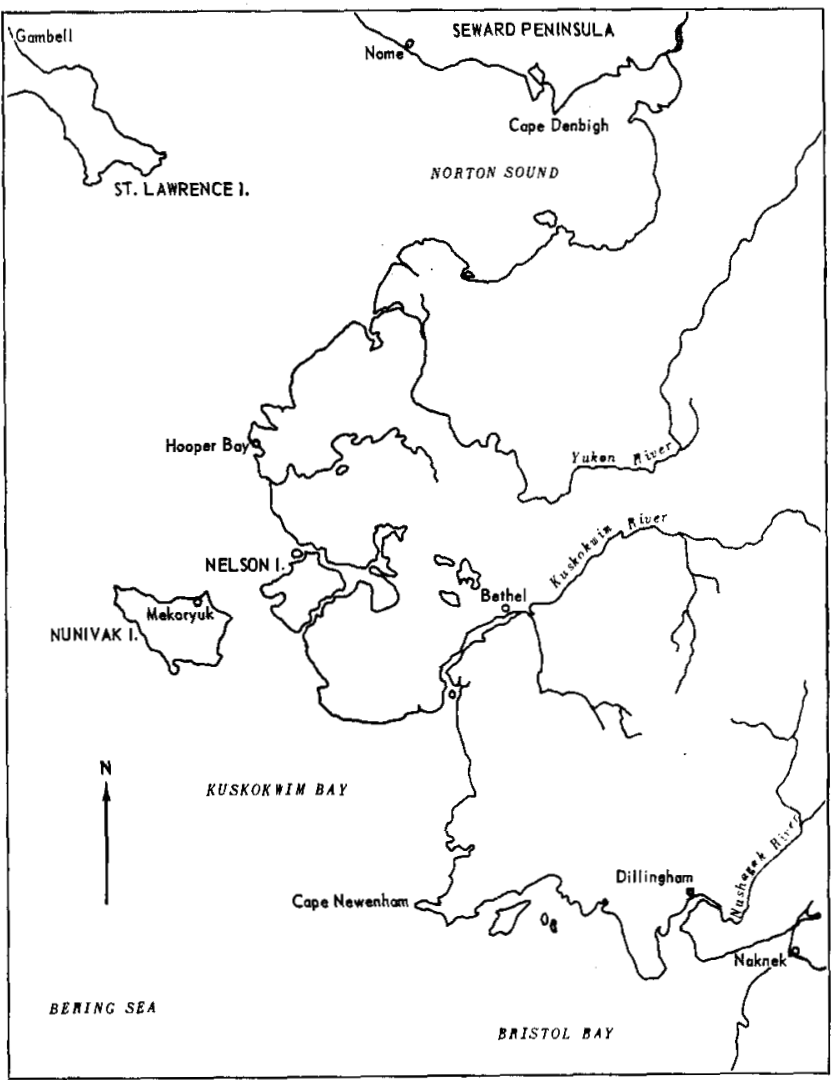

COST ANALYSES
FIG. 1. Map of western Alaska (scale approx. $1 \mathrm{~cm}$ to $80 \mathrm{~km}$ ).

In Table 1 a breakdown is provided of the annual expenses involved (at 1975 prices) in the acquisition of traditional foods by an average family of six persons, and hence the costs per pound (kilogram) to them of the various items.

In the calculations, no money values are imputed to the periods of time spent in hunting and fishing, because the persons concerned participated in these activities at times when they were not normally engaged in wage labour (i.e., holidays and vacations). 
TABLE 1. Breakdown of acquisition costs of traditional foods.

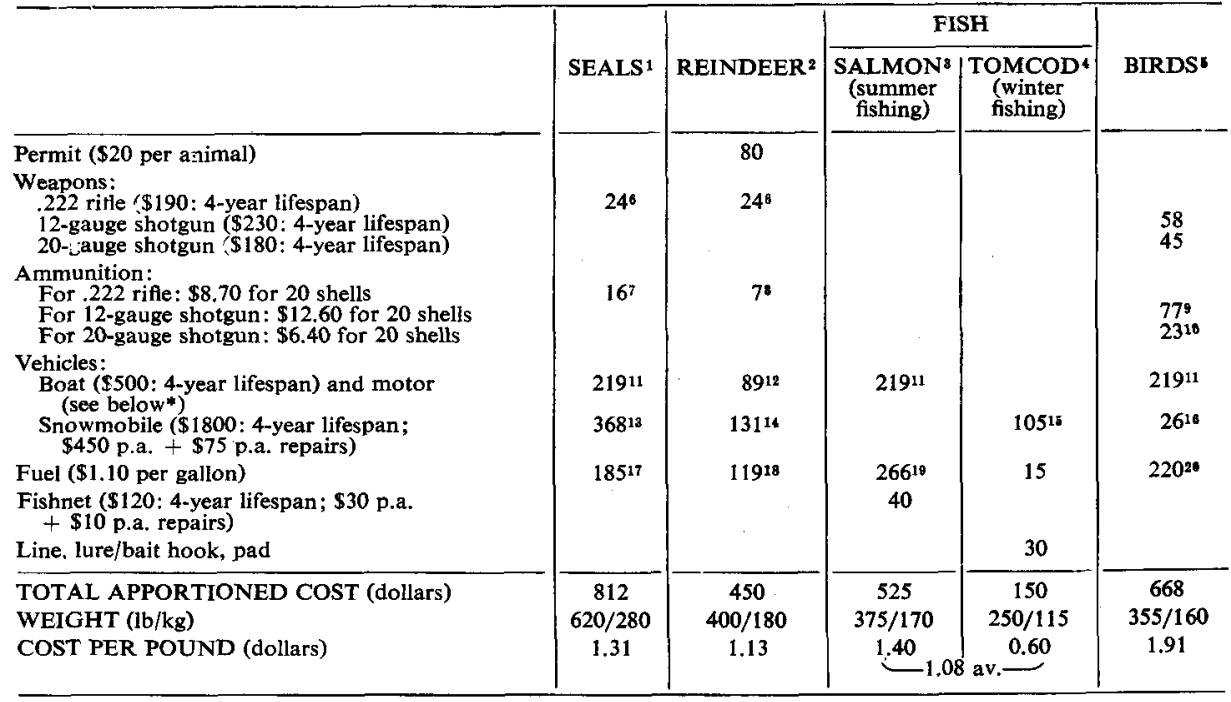

$\{1.40$ H.P. $\$ 900+\$ 60$ for fuel tank; 4-yr. lifespan $(\$ 240$ p.a. $+\$ 50$ p.a. repairs)

$*\{1.20$ H.P. $\$ 700+\$ 60$ for fuel tank; 4-yr. lifespan ( $\$ 190$ p.a. $+\$ 50$ p.a. repairs)

15 common seal plus 1 bearded: total weight $=620 \mathrm{lb} / 282 \mathrm{~kg}$ (dressed meat and oil): 3 hunts, each averaging 7 days

${ }^{24}$ reindeer: total weight $=400 \mathrm{lb} / 182 \mathrm{~kg}$ (dressed meat): 2 hunts, each of 5 days

8250 salmon $-375 \mathrm{lb}$ dried $/ 170 \mathrm{~kg} \mathrm{(21/2}$ lb dressed each $=11 / 2 \mathrm{lb}$ dried): 1 trip of 14 days

4900 tomcod $-300 \mathrm{lb}$ fresh (one quarter of catch $(75 \mathrm{lb}$ ) is reduced to weight of $25 \mathrm{lb}$ dried) $\therefore$ total weight $=225 \mathrm{lb}+25 \mathrm{lb}=250 \mathrm{lb} / 114 \mathrm{~kg}: 30 \mathrm{trips}$

${ }^{3} 25^{\circ}$ geese @ $4 \mathrm{lb}=100 \mathrm{lb} ; 60$ ducks @ $3 \mathrm{lb}=180 \mathrm{lb} ; 25$ ptarmigan, cormorant, loon, etc. $@ 3 \mathrm{lb}=75 \mathrm{lb} \cdot \cdot$ total weight $=355 \mathrm{lb} / 161 \mathrm{~kg}: 4 \mathrm{trips}$, each of 4 days

Use factor 0.50

${ }^{7} 6$ shells per seal

84 shells per reindeer

919 geese and 36 ducks ( 2 shells per bird) +12 ptarmigan, cormorant, loon, etc. (1 shell per bird)

${ }^{10} 6$ geese and 24 ducks ( 2 shells per bird) +12 ptarmigan, cormorant, loon, etc. (1 shell per bird)

"Use factor 0.33

${ }^{12}$ Use factor 0.13

${ }^{13}$ Use factor 0.70

${ }^{14}$ Use factor 0.25

${ }^{13}$ Use factor 0.20

${ }^{18}$ Use factor 0.05

${ }^{17} 14$ days @6 hours per day @ 2 gall./hour

1810 days @6 hours per day @ 1.8 gall./hour

104 days to and from fishcamp: 32 hours @ 3.8 gall./hour

10 days at fishcamp: 60 hours @2 gall. /hour

2016 days hunting: BOAT 11.2 days $(70 \%) @ 5$ hours per day @ 2 gall./hour

SNOWMOBILE 4.8 days $(30 \%) @ 5$ hours per day @ 1.8 gall./hour

Since equipment was used for obtaining the whole range of traditional foods, the costs of it are amortized over a "primary life-span" of four years - this period being arrived at by the author through observations he made in the course of contacts with the user-families over a period of ten years as well as conversations with them about the equipment.

The majority of natives engaged in traditional hunting and fishing activities are aware of some of the costs involved - the latest incurred usually being uppermost in their minds - but only rarely do they understand that costs of equipment in general use should be amortized over a period of years, rather than being treated as annual costs.

In the amortization of equipment employed in these traditional hunting and 
fishing activities, no account is taken of the use of any of it for recreational purposes. To do so might serve to decrease the final cost of the game obtained, but since recreational use of equipment is not a necessary part of hunting, etc., it has been disregarded. As modern Eskimos increasingly come to make a distinction between work and recreation, it may at some time in the future become necessary to include non-productive or recreational use of equipment in amortization calculations.

To the extent that costs of equipment are common to almost all of the calculations used in Table 1, the factor that makes for the biggest difference in the final cost per pound (kilogram) is the total amount of game secured of a particular kind. Birds are the most expensive because they yield the least amount by weight of all the game sought. Reindeer are the most cost-efficient because, despite the fact that eighty dollars' worth of permits are necessary for four of them, they require relatively little time to hunt, and therefore yield a substantial amount of meat for the time involved. Although a greater weight of seal flesh than reindeer is obtained, equipment amortization is greater for seal hunting, making it a more expensive activity than reindeer hunting. Skins and hides procured during hunts are not included in these cost assessments, since they cannot be regarded as edible items; most of them are utilized by the family of the hunter rather than being sold for cash.

Evidence of greater yields of game and fish is provided in other studies of traditional Eskimo subsistence activities, but nine out of the thirteen families the author maintained contact with had heads of households involved in some aspect of wage labour at the time of these observations.

Table 2 presents costs of both traditional foods, as computed in Table 1, and the local-store equivalent of imported foods, for purposes of comparison. The overall average cost of the former is $\$ 1.30$ per pound $(\$ 2.77$ per $\mathrm{kg}$ ), $\$ 0.89$ per pound less than the loaded average price of imported meats $(\$ 2.19)$. This figure acquires greater meaning when it is considered in a more general context.

TABLE 2. Comparison of costs of imported and traditional meats and fish.

\begin{tabular}{|c|c|c|c|c|c|}
\hline \multicolumn{4}{|c|}{ Imported meats and fish1 } & \multirow{2}{*}{\multicolumn{2}{|c|}{ Traditional foods 2}} \\
\hline \multicolumn{2}{|c|}{$\begin{array}{l}\text { Fresh or frozen } \\
\text { (with frequency loading) }\end{array}$} & \multicolumn{2}{|c|}{$\begin{array}{c}\text { Canned } 3 \\
\text { (with frequency loading) }\end{array}$} & & \\
\hline $\begin{array}{l}\text { Ground beef } \\
\text { Stew meat } \\
\text { Round roast } \\
\text { Cubed beef } \\
\text { Chicken } \\
\text { Fish } \\
\text { Hotdogs }{ }^{4}\end{array}$ & $\begin{array}{l}\$ 1.79 \times 3.0 \\
\$ 2.15 \times 2.0 \\
\$ 3.29 \times 2.0 \\
\$ 2.98 \times 0.5 \\
\$ 1.45 \times 2.0 \\
\$ 2.13 \times 0.5 \\
\$ 1.99 \times 2.0\end{array}$ & $\begin{array}{l}\begin{array}{l}\text { Bonita } \\
\text { Chicken } \\
\text { Tuna }\end{array} \\
\text { Salmon } \\
\text { Ham }\end{array}$ & $\begin{array}{l}\$ 1.60 \times 1.0 \\
\$ 1.02 \times 2.5 \\
\$ 3.25 \times 3.0 \\
\$ 6.12 \times 0.5 \\
\$ 2.62 \times 2.0\end{array}$ & $\begin{array}{l}\text { Seal } \\
\text { Reindeer } \\
\text { Fish } \\
\text { Birds }\end{array}$ & $\begin{array}{l}\$ 1.32 \\
\$ 1.13 \\
\$ 1.09 \\
\$ 1.91\end{array}$ \\
\hline Average & $\$ 2.14$ & Average & $\$ 2.23$ & & \\
\hline
\end{tabular}

1Bethel, Alaska, August 1975 (prices given are per pound as averaged for three supermarkets) 2See Table 1 (prices given are per pound)

3Includes liquid, gelatin and juices

${ }^{4}$ Cheapest variety available 
First, in the case of canned meats, the liquids or gelatin in which the product is packaged have an effect on the price. If they were removed, the price per pound (kg) would be higher for imported canned meats. Second, the weights of fish used in Table 1 are final ones which take account of the considerable losses incurred during drying; if fresh weights were used exclusively, the cost of salmon would drop to $\$ 0.84$ per pound and that of tomcod to $\$ 0.50$. (Some seal meat is also dried, but the proportion is not nearly as high as that of fish, and so was not taken into account in this study.) A third point, which will be developed in the discussion which follows these cost analyses, is that traditional meats differ nutritionally from canned meats, particularly those which include vegetables and other additives.

If each family obtained 2,000 pounds $(908 \mathrm{~kg}$ ) of traditional food per year, (see Table 1), it could because of the differential of $\$ 0.89$ between the cost per pound of traditional and imported foods (see Table 2) achieve an annual saving of $\$ 1,780$. For the community of Mekoryuk (43 families), the annual saving could be over $\$ 76,000$.

Families obtaining all of their food requirements through traditional game consumption were not encountered on Nunivak Island. Nor were any known of in the Yukon-Kuskokwim delta area. To this extent, the maximum possible savings through use of traditional foods will never be realized. At a mean income of $\$ 6,200$ per family (Nowak 1975 a p. 24), a savings of $\$ 1,780$ constitutes $29 \%$ of a family's annual income. In parts of southwestern Alaska where income levels are lower (Mason 1975) the economic significance of traditional subsistence activities is even greater. There a family with an income of $\$ 4,500$, obtaining 2,000 pounds of traditional game could save a little over $39 \%$ of that income.

Another factor which needs to be considered is the relationship between price increases of the equipment required to pursue traditional subsistence activities and those for imported foods. Over the period to which the data presented in this paper pertain (1973-75), the author found from comparisons of specimen prices that inflation affected major equipment to a greater extent than groceries. The present study extended over insufficient time for reliable predictions to be made of what the future price differentials between imported foods and traditional foods are likely to be; but if equipment continues to become relatively more expensive than store items, the present savings realized through pursuit of traditional foods will continue to diminish until at some time in the future they may cease to exist at all.

\section{DIET, LIFESTYLE AND CONVENIENCE}

Since substantial increases are occurring in the prices of equipment necessary for the obtaining of traditional foods, average costs of the latter, as computed by the methods of Table 1 , could in time possibly exceed average prices of imported meats (Table 2). The degree of equivalence in nutritional value between traditional and import-based diets therefore constantly needs to be taken into consideration in addition to simple differentials in overall outlay per pound (kilogram). Traditional foods are rich in protein and fats, whereas those which replace them have considerable carbohydrate content. In other words, diets examined in the course 
of the present study which consisted of a high proportion of imported foods were also ones in which cereals (rice, wheat, barley, etc.) and potatoes constituted substantial parts. Meat was always present in these diets, but often in a modified form such as wieners, beef stew, or canned meat products. Such products are consumed not necessarily because of a great liking for their taste, but rather because they are relatively cheap (when compared to frozen meats), have a long shelf-life (usually being canned), and are widely available. Nutritionally, canned processed meats may be inferior to fresh, dried or frozen meats (Robbins 1974 pp. 171-8).

The above discussion concerns primarily the evening meal, which is the main one of the day. Both breakfast and lunch are light compared to it. In Bethel and Mekoryuk, observations suggest that, for many, breakfast consists of nothing more than coffee or tea, plus perhaps a cracker or two with jam, whether or not the families concerned make little or great use of imported foods. Cold cereals, seen in almost every household with children, were prepared with fresh or canned milk and sugar. Coffee was generally drunk with added milk and sugar. Only rarely did breakfast include bacon and eggs, and then only in those of the families observed who had had considerable experience of life outside their villages and had steady cash incomes.

A greater difference was observed in the field lunches in which traditional food (dry fish and seal oil) accompanied crackers and coffee. Families eating lunch at home tended to follow the pattern of the main meal, some of them replacing dried salmon and seal oil with peanut butter, canned meats and jam. Soup was also a common lunch item, but varied from the dried imported kinds to ones prepared locally from reindeer, fish, bird or seal meat.

In terms of cost differences, breakfast showed the least range inasmuch as coffee, crackers and jam were the main foods consumed in nearly all of the cases examined. Hot cereals, imported sweet rolls, hotcakes, or even eggs were often to be found in the homes of the more acculturated families. In Mekoryuk, about a quarter of the families fell into this category. Lunches appeared to be of the same pattern as that observed in the case of the main meal: those based entirely on imported foods were richer in carbohydrates than those involving traditional foods, and were also more expensive - particularly if adjustments are made to ensure approximate nutritive equivalence.

Along with other manifestations of change, the availability of wage labour profoundly affects the Eskimo's sense of time. A definite schedule is suddenly introduced into a lifestyle which previously had been little concerned with a precisely-structured day. Eating habits and diet are almost always affected by a switch to wage labour (Nowak 1975b). As is also the case outside the Arctic, a price has to be paid for a change to a diet consisting to some extent of semiprepared convenience foods; for the cost of these foods is almost always higher than that of the component ingredients obtained separately, and higher still when nutritive quality is taken into consideration (Nowak 1975b p. 56). The foregoing considerations may however be outweighed in individual judgements by the enormous advantages of having a steady income. Such an income itself enables a family to consciously choose the degree to which it will either participate in 
traditional subsistence activities or buy imported foods (Nowak 1975a p. 29).

The use of semi-prepared imported foods is likely to depend on both how a family allots its time, as these foods take less time to prepare, and the degree to which the foods have become familiar. The latter is almost always determined by how much time the family has spent away from its village in a larger town or city. These points are related in that at least the head of those families which spend periods of time at larger centres is usually employed for wages on a fixed-hour schedule. The steady income enables such families to purchase convenience foods, the taste for and use of which has become part of their lifestyle (Nowak 1975b pp. 57-58).

Even in larger towns or cities, however, preference for convenience foods cannot be taken entirely for granted. In many situations such foods may be used because of the pressure of time and because of the unavailability of a traditional food. For instance, seal meat is not continuously available from stores in Bethel, and when it is, commands a price that fails to make it more economical than imported meats. With the exception of reindeer and salmon, other game is not available at retail stores. Reindeer is sometimes found in Bethel because one of the retail grocery stores there will buy quantities of reindeer meat from Mekoryuk's Bering Sea Reindeer Products Corporation when the size of the annual slaughter permits this. Salmon and reindeer are not cheaper than imported meats or fish in Bethel, so that store purchase of either of these foods reflects taste preference rather than an attempt to save.

A detailed comparison between the intensities with which traditional subsistence activities are pursued in Bethel and in surrounding smaller villages is not at present possible; but most inhabitants of these villages still appear to rely upon a regular supply of traditional foods (B.I.A. 1975; Nowak 1975a p. 29). Bethel residents tend to consume a higher percentage of imported food because (a) those employed have less time to devote to subsistence activities; (b) the presence of three supermarket-type stores makes a wide variety of imported foods readily accessible; (c) a higher percentage of its people have attended secondary schools (which until 1970 were all boarding establishments in larger population centres), and in the process became more accustomed to imported foods; and (d) a greater percentage of its population is transient (a family may live there with relatives, while one of their members is in the hospital or working at a temporary job, and during this time it is likely to subsist on store foods).

Since food stamps have become available to inhabitants of large and small villages alike, Kuskokwim Eskimo families that formerly bought mainly staple products (flour, sugar, shortening, coffee, tea, etc.), now purchase frozen prepared dinners, cake mixes, and other convenience foods with increasing frequency especially in Bethel, where these foods are obtainable in wide variety. The women are in consequence not obliged to spend as much time preparing food as in the past; they are able to take on regular or casual jobs, do handicrafts, undertake more things at home or engage in social activities. Similar changes have been observed in other parts of the Arctic and Subarctic (Honigmann 1975).

Many of the native people from villages acquire new habits as a result of trips to Bethel or to Anchorage, where they become acquainted with short-order 
establishments, restaurants, and the supermarket with its very large variety of American foods. Ninety-seven per cent of the residents of Mekoryuk interviewed during the summer of 1975 said that they had been to Bethel at least once during the preceding year. Over fifty per cent had also visited Anchorage during the same period. Thus, even if an individual from Mekoryuk clearly prefers traditional foods and consumes them almost exclusively at home, it is unlikely that he or she will be unaware of the availability of modern Western foods. While Bethel does not presently have the "fast-food" establishments which have become a prominent feature of Anchorage in recent years, its community liquor store was remodelled into a snack-and-short-order shop after its citizens voted to ban liquor sales early in 1974. From observations made during the summer of 1975, it appears that the shop has been frequented predominantly by Bethel's youth, although a number of adult Eskimos have been seen there too.

While it is possible that families could have procured (and probably, often do procure) more than the 1,100 pounds $(500 \mathrm{~kg}$ ) of game/fish each, as shown in this study, there is no indication of a desire on their part to subsist entirely on a traditional diet. Indeed, the income from their wage employment permits them to purchase a variety of Western foods which they consciously select and consume as part of their daily diet.

Kemp (1971 p. 113) has made an assessment of a Baffin Island community's purchases of imported store items in kilocalories of food energy rather than in pounds of food items obtained. His results cannot therefore be directly compared with those of the present study. Furthermore, Kemp's study was carried out almost a decade earlier (1967-68), and in a more isolated village. Even there, however, one of the families studied changed its diet radically from one consisting of $33 \%$ protein to one of store purchases, predominantly carbohydrate (62\%), and containing only $9 \%$ protein (Kemp 1971 p. 113).

The assessment of the value of "country food" made by Usher (1976 p. 115) indicates that, on a substitution basis, a family dependent primarily on traditional subsistence might obtain the equivalent of $\$ 6,200$ worth of meat, whereas one engaged in full-time labour, and hunting only on weekends and holidays, might expect to shoot four caribou and 30 geese and catch 500 pounds $(227 \mathrm{~kg})$ of fish - worth in all about $\$ 2,800$. The latter value approaches the figures arrived at in the present study.

\section{CONCLUSION}

An attempt has been made in this paper to demonstrate that, while it is difficult to estimate the monetary value of traditional subsistence foods, such figures are useful in an assessment of the actual and potential savings possible through their use. The economic significance of the use of traditional foods is at present quite considerable, although it is possible that inflation may gradually cause it to be eroded. Whether it will ever entirely disappear is uncertain.

Although the world of the Arctic peoples is rapidly changing, subsistence activities will assuredly always play a major role in their health and well-being. Almost all investigators who have written about Eskimo and Indian culture have 
concluded that the pattern of subsistence activities has changed markedly over the last few decades. They have also shown that the health of these people is in part related to the foods that they subsist on (G. Brenneman, Director, Public Health Service Hospital, Bethel, Alaska, personal communication, 1975; Fortuine 1966; Nowak 1975b; Schaefer 1971; Sinclair 1953). It seems highly likely that in the future these peoples will increasingly use and rely on foodstuffs imported from Canada and the rest of the United States.

\section{REFERENCES}

B.I.A. (Bureau of Indian Affairs). 1975. A Survey of Natives' Views; 2(c) Report, Task 3. (On file at offices of U.S. Department of the Interior.)

FORTUINE, R. 1966. Health conditions among the Eskimos of the Yukon-Kuskokwim delta area. Polar Notes, (6):7-21.

honigmanN, J.J. 1975. Five northern towns. Anthropological Papers of the University of Alaska, 17(1):1-67.

KEMP, W.B. 1971. The flow of energy in a hunting society. Scientific American, 224(3):104-16. MASON, L.D. 1975. Hard times along the Kuskokwim. Natural History, 84(7):66-73.

NowaK, M. 1975a. Subsistence trends in a modern Eskimo community. Arctic, 28(1):21-34. 1975b. The impact of "convenience" foods on a community in western

Alaska. Anthropological Papers of the University of Alaska, 17(2):55-59. RoBbins, w. 1974. The American Food Scandal. New York: Wm. Morrow. SCHAEFER, o. 1971. When the Eskimo comes to town. Nutrition Today, 6(6):8-16.

SINCLAIR, H.M. 1953. The diet of Canadian Indians and Eskimos. Proceedings of the Nutrition Society, 12:69-82.

USHER, P.J. 1976. Evaluating country food in the northern native economy. Arctic, 29(2):105-20. 